\title{
Do accessory parameters affect the outcome of the endoscopic procedures in female infertile patients?: an experience at a single tertiary care center
}

\author{
Namita Agrawal ${ }^{1 *}$, Poonam Yadav, S. Fayyaz ${ }^{1}$, Tarun Kumar Jain ${ }^{2}$
}

\begin{abstract}
${ }^{1}$ Department of Obstetrics and Gynecology, Santokba Durlabhji Memorial Hospital, Jaipur, Rajasthan, India ${ }^{2}$ Department of Nuclear Medicine and Biostatistics, Mahatma Gandhi Medical College and Hospital, Jaipur, Rajasthan, India
\end{abstract}

Received: 11 March 2019

Accepted: 09 April 2019

\section{*Correspondence:}

Dr. Namita Agrawal,

E-mail: namitaagarwalsms@gmail.com

Copyright: () the author(s), publisher and licensee Medip Academy. This is an open-access article distributed under the terms of the Creative Commons Attribution Non-Commercial License, which permits unrestricted non-commercial use, distribution, and reproduction in any medium, provided the original work is properly cited.

\section{ABSTRACT}

Background: In modern era, endoscopic methods are commonly used in evaluation of female infertility. Hysterolaparoscopy is such a real time theranostic modality for anatomical causes of the infertility. The objective of this study was to evaluate the effect of accessory parameters (Age, Body mass index, duration of infertility, Rhesus factor, menstruation history and hemoglobin) on success rate of endoscopic procedures in terms of achieving pregnancy.

Methods: A total 157 female infertile patients (Mean \pm standard deviation 27.72 \pm 3.82 years) were recruited in present study. During initial assessment detailed history was taken and hysterolaparoscopy was performed. The observed structural abnormalities on hysterolaparoscopy during diagnostic work up were tackled at same time if possible. After procedure, patients were counselled for regular sexual activity. The follow-up of all patients was done for 12 months.

Results: A total 157 female infertile patients were recruited and divided into primary $93(59.2 \%)$ and secondary infertile $64(41.74 \%)$ patients on basis of obstetric history. The average age, BMI, hemoglobin and duration of infertility were 27.7 years, $21.8 \mathrm{~kg} / \mathrm{m}^{2}, 12.3 \mathrm{gm}$ and 3.9 years respectively. Out of 157 patients, anatomical abnormalities were detected in 125 patients during Hysterolaparoscopy and distributed in $77 / 93(82.8 \%)$ primary and 48/64 (75\%) secondary infertile patients. Of 125 patients with abnormal hysterolaparoscopic findings, 121 underwent active intervention and on follow up, 43 patients were conceived. We found that age; BMI, Rhesus factor, menstruation history and duration of the infertility were not correlated with fertility outcome while hemoglobin level was significantly correlated with conception rate.

Conclusions: Authors concluded that outcome of the hysterolaparoscopy in female infertile patients is significantly depends upon hemoglobin levels, however outcome is irrelevant to age, duration of infertility, Rhesus factor and body mass index.

Keywords: Age, Body mass index, Duration of infertility, Fetal Hysterolaparoscopy, Hemoglobin level, Infertility, Pregnancy

\section{INTRODUCTION}

Infertility is a medical condition with important psychological, economical, demographic, and medical implications. This is one of the major problems of human reproduction that haunts societies. ${ }^{1}$ The sufferers from the infertility feel depression, grief, guilt, shame, and incompleteness. Clinically, infertility defined as, inability 
to conceive even after twelve months of regular, timely, unprotected intercourse in women less than 35 years of age; and after six months of regular intercourse in women 35 years or older. ${ }^{2,3}$

The responsible causes of infertility may be subdivided into anatomical and functional. In anatomical causes such as ovarian cyst/ tumor, tubal damage, endometriosis, and congenital (septate uterus) /acquired (myomas and synechiae) uterine anomalies etc, surgical intervention is important to improve the fertility outcome. ${ }^{3-5}$

To localize the anatomical cusses, noninvasive pelvic ultrasonography is commonly performed imaging. An additional invasive investigation such as laparoscopy and hysteroscopy may be performed according to the clinical presentation and the results of the preliminary tests. ${ }^{1,3,4-11}$ The published literature as well as our experience, illustrate that routine examination and pelvic ultrasonography is not enough to evaluate pelvic pathologies of infertile women since subtle changes in the form of small polyps, adhesions, and sub-endometrial fibroid seedling, which influence fertility, can be missed. These subtle changes are better picked up on magnification with endoscopic procedures. ${ }^{4-6,12-14}$

The endoscopic methods such as laparoscopy and hysteroscopy are commonly used in an evaluation of abdomen and pelvic cause's of infertility. These endoscopic methods (hysterolaparoscopy) are diagnostic as well as therapeutic for pelvic and abdominal pathologies in the same sitting ${ }^{4-6}$ The hysterolaparoscopy is an invasive and relatively costlier investigation and we want to investigate the impact of age, body mass index, duration of infertility, Rhesus Factor, menstrual history and hemoglobin level in infertile woman in fertility outcome who are underwent for hysterolaparoscopy. In my best knowledge in the described literature, no single study had mentioned the impact of accessory parameters in success rate of the hysterolaparoscopy in term of achieving pregnancy after treatment. So, aim of the present study was to evaluate the effect of the accessory parameters (age, body mass index, duration of infertility, menstruation history, Rhesus factor and hemoglobin) on success rate of endoscopic procedures in achievement of fetal cardiac activity whichever is earlier.

\section{METHODS}

The present study was prospective analytic study and carried out between March 2016 to March 2018 at the Department of Obstetrics and Gynaecology at Tertiary Care Centre, Rajasthan, India.

\section{Inclusion criteria}

- Infertile female patients with age 19-35 years,

- Regular and irregular menstrual cycle,

- Couple who did not conceive even after at least oneyear of unprotected regular sexual intercourse,
- Normal male partner seminogram, normal or abnormal ultrasonography, hysterosalpingogram whenever is available,

- Investigations such as hemoglobin, complete blood count (CBC), Erythrocyte sedimentation rate (ESR), random blood sugar, thyroid function test- within normal limit and ovulatory function,

- Husband semen analysis, hormonal profile (TSH/FSH/LH/Prolactin) and APLA (anti phosphor lipid antibody) levels (if available and only in secondary infertility)-within normal limit.

\section{Exclusion criteria}

- Age $<19$ year or $>35$ year,

- Abnormal husband semen analysis,

- Abnormal hormonal profile,

- Active genitourinary infection,

- Any treatment, chronic illness and MPA (Medroxy progesterone acetate) contraception that imparts a negative effect on fertility.

Infertile female patients, age between 19-35 years were registered to participate in the study after taking the informed and written consent. After detailed history (together as well as separately) and clinical examination (general, systemic and gynecological examination), routine investigations were performed. In the detailed history, authors found that patients have already taken medical management for different pathologies for example clomiphene citrate in case of poly cystic ovarian syndrome (PCOS). So in brief we can say all included patients were not responding to the medical management. After considering the exclusion criteria and contraindications of the operative procedure, hysteroscopy and laparoscopy were concurrently performed at department of obstetrics and gynaecology at tertiary care centre, Rajasthan, India. The uterus, anterior and posterior cul-de-sacs, fallopian tubes, ovaries, ovarian fossae, pelvic peritoneum, appendix and liver surface were examined during the procedure, if some abnormalities was seen and it was noted down. Chromopertubation (CPT) was performed in all cases. Therapeutic interventions were performed at the same sitting in form of ovarian drilling, adhesiolysis, ablation of endometriotic spots, cystectomy, synechiolysis, septum resection, polypectomy, cannulation etc., if required. After offering the successful treatment, patient's were advised for regular sexual activity. Approval of the institutional ethical committee was obtained for this prospective study. In view of the prospective study design, written informed consent was obtained.

\section{Statistical analysis}

All enlisted patients were divided into two subgroups, primary and secondary infertility and the detected pathologies and treatment in each group during the hystero-laparoscopic procedure were noted. The analysis between the two groups and continuous variables were 
summarized as mean and standard deviation, whereas nominal/categorical variables were summarized as proportions. Parametric tests (Student t-test) were used for analysis of continuous variables while Chi-square was used for nominal/categorical variables. To assess the correlation between the parameters Pearson correlation coefficient is also calculated. The ' $p$ ' value $<0.05$ was considered as significant. IBM-SPSS version 22.0 software was used for all statistical analysis.

\section{RESULTS}

\section{Patient's demographics and clinical parameters}

Around 157 female patients with infertility were included in the present study. The mean age of patients was 27.72 years (range of 19-35 years). All recruited patients fulfilled the inclusion criteria of the present study. On the basis of obstetric history, patients were divided into primary and secondary infertility. Of the 157 infertile female patients, $93(59.2 \%)$ were of primary infertility and remaining $64(41.74 \%)$ were secondary infertility patients. The characteristics of all patients are given in Table 1.

The mean age of secondary infertility patients was significantly higher $(\mathrm{p}<0.002)$ than primary infertility patients. The BMI of primary and secondary infertility patients did not show statistically significant difference (p 0.838) (Table 1).

Table 1: Characteristics of infertility patients (age, BMI).

\begin{tabular}{|lll|}
\hline \multirow{2}{*}{ Infertility (Total no. of patients) } & 157 \\
\hline \multirow{2}{*}{ BMI (years) $\left(\mathrm{kg} / \mathrm{m}^{2}\right)$} & Mean \pm SD & $27.72 \pm 3.82$ \\
\cline { 2 - 3 } & Range & $19-35$ \\
\cline { 2 - 3 } & Rean \pm SD & $21.80 \pm 3.03$ \\
\hline Primary infertility (No. of patients) & $93 / 157(59.2 \%)$ \\
\hline \multirow{2}{*}{ Age (years) } & Mean \pm SD & $26.59 \pm 3.23$ \\
\cline { 2 - 3 } & Range & $19-34$ \\
\hline \multirow{2}{*}{ BMI $\left(\mathrm{kg} / \mathrm{m}^{2}\right)$} & Mean \pm SD & $21.84 \pm 3.30$ \\
\cline { 2 - 3 } & Range & $16-33.3$ \\
\hline \multirow{2}{*}{$\begin{array}{l}\text { Secondary infertility }(\mathrm{No} . \text { of } \\
\text { patients })\end{array}$} & Mean \pm SD & $64 / 157$ \\
\hline \multirow{2}{*}{ Age (years) } & Range & $29.35 \pm 4.04$ \\
\hline \multirow{2}{*}{ BMI $\left(\mathrm{kg} / \mathrm{m}^{2}\right)$} & Mean \pm SD & $20-35$ \\
\cline { 2 - 3 } & Range & $21.7 \pm 2.62$ \\
\hline
\end{tabular}

Table 2: Characteristics of primary and secondary infertility patients (Duration of infertility, hemoglobin levels, blood group, menstruation, and relevant past medical and surgical histories)

\begin{tabular}{|c|c|c|c|c|}
\hline Parameters & & Primary infertility & Secondary infertility & P value \\
\hline \multirow{2}{*}{$\begin{array}{l}\text { Duration of infertility } \\
\text { (years) }\end{array}$} & Mean \pm standard deviation & $4.25 \pm 1.93$ & $3.4 \pm 1.56$ & \multirow{2}{*}{0.005} \\
\hline & Range & $2-12$ & $2-8$ & \\
\hline \multirow{2}{*}{ Hemoglobin (gm/dl) } & Mean \pm standard deviation & $12.3 \pm 1.21$ & $12.2 \pm 1.25$ & \multirow{2}{*}{0.616} \\
\hline & Range & $8.5-15.5$ & $8.9-16.7$ & \\
\hline \multirow{2}{*}{$\begin{array}{l}\text { Blood group (patient's } \\
\text { number) }\end{array}$} & Rh positive & $85 / 93(91.4 \%)$ & $59 / 64(92.2 \%)$ & \multirow{2}{*}{0.687} \\
\hline & Rh Negative & $8 / 93(8.6 \%)$ & $5 / 64(7.8 \%)$ & \\
\hline \multirow{2}{*}{$\begin{array}{l}\text { Menstruation (patient's } \\
\text { number) }\end{array}$} & RNF & $67 / 93(72.1 \%)$ & $49 / 64(76.6 \%)$ & \multirow{2}{*}{0.546} \\
\hline & Other than RNF & $26 / 93(27.9 \%)$ & $15 / 64(23.4 \%)$ & \\
\hline \multirow{2}{*}{$\begin{array}{l}\text { Relevant past medical history } \\
\text { (patient's number) }\end{array}$} & Positive & $3 / 93(3.2 \%)$ & $3 / 64(4.7 \%)$ & \\
\hline & Negative & $90 / 93(96.7 \%)$ & $61 / 64(95.3 \%)$ & \\
\hline \multirow{2}{*}{$\begin{array}{l}\text { Relevant past surgical history } \\
\text { (patient's number) }\end{array}$} & Positive & $3 / 93(3.2 \%)$ & $30 / 64(46.9 \%)$ & \\
\hline & Negative & $90 / 93(96.7 \%)$ & $34 / 64(53.1 \%)$ & \\
\hline
\end{tabular}

RNF- Regular normal flow

All recruited primary and secondary infertility patients underwent a detailed history. The husband's semen analysis, general physical and pelvic examinations were within normal limits for all included patients. The summarized characteristics of primary and secondary infertility patients are given in Table 2 .

Among primary infertility group, past medical history was relevant in $3 / 93$ patients. The past medical history included successfully treated pelvic inflammatory disease, pulmonary and lymph nodal tuberculosis in each patient. The relevant past surgical history in 3/93 patients included open cystectomy, laparoscopic and open myomectomy.

The duration of infertility in primary infertility patients was significantly higher than the secondary infertility patients $(\mathrm{p}<0.005)$. The menstruation history $(\mathrm{p} \sim 0.546)$, Hemoglobin (gm/dl) (0.616) and Rh positivity (p 0.687) among the primary and secondary infertility patients did not show statistical difference (Table 2). 
Table 3: Tabular summaries of results after hysterolaparoscopy in combined and primary and secondary infertility patients.

\begin{tabular}{|llll|}
\hline Parameters & $\begin{array}{l}\text { Combined } \\
\text { (No. of patients) }\end{array}$ & $\begin{array}{l}\text { Primary } \\
\text { (No. of patients) }\end{array}$ & $\begin{array}{l}\text { Secondary } \\
\text { (No. of patients) }\end{array}$ \\
\hline Infertile patients & 157 & 93 & 64 \\
\hline Hysterolaparoscopic abnormal & 125 & 77 & 48 \\
\hline Hysterolaparoscopic tackle & 121 & 73 & 48 \\
\hline $\begin{array}{l}\text { Conceived on follow up (Patient who } \\
\text { underwent HL intervention) }\end{array}$ & $43 / 121(35.5 \%)$ & $28 / 73(38.3 \%)$ & $15 / 48(31.2 \%)$ \\
\hline
\end{tabular}
$\mathrm{P} \sim 0.457$

Table 4: Correlation between the clinical parameters and fertility outcome in combined and primary and secondary infertility patients.

\begin{tabular}{|c|c|c|c|c|}
\hline $\begin{array}{l}\text { Clinical } \\
\text { parameters }\end{array}$ & Parameters & $\begin{array}{l}\text { Combined } \\
\text { infertility }\end{array}$ & Primary infertility & $\begin{array}{l}\text { Secondary } \\
\text { infertility }\end{array}$ \\
\hline \multirow{3}{*}{ Age (Years) } & Correlation coefficient $r$ & 0.06460 & -0.04110 & 0.2084 \\
\hline & Significance level (p value) & $\mathrm{P}=0.4215$ & $P=0.6957$ & $\mathrm{P}=0.0984$ \\
\hline & $95 \%$ Confidence interval for $\mathrm{r}$ & -0.09298 to 0.2190 & -0.2428 to 0.1640 & -0.03941 to 0.4321 \\
\hline \multirow{3}{*}{$\begin{array}{l}\text { BMI } \\
\text { (Body mass } \\
\text { index) }\end{array}$} & Correlation coefficient $\mathrm{r}$ & -0.08052 & -0.1042 & -0.03860 \\
\hline & Significance level (p value) & $\mathrm{P}=0.3161$ & $\mathrm{P}=0.3201$ & $P=0.7620$ \\
\hline & $95 \%$ Confidence interval for $r$ & -0.2342 to 0.07709 & -0.3015 to 0.1017 & -0.2817 to 0.2092 \\
\hline \multirow{3}{*}{$\begin{array}{l}\text { Hemoglobin } \\
(\mathrm{gm} \%)\end{array}$} & Correlation coefficient $r$ & 0.2206 & 0.2220 & 0.2180 \\
\hline & Significance level (p value) & $\mathrm{P}=0.0055$ & $\mathrm{P}=0.0324$ & $\mathrm{P}=0.0835$ \\
\hline & $95 \%$ Confidence interval for $\mathrm{r}$ & 0.06622 to 0.3646 & 0.01919 to 0.4073 & -0.02935 to 0.4403 \\
\hline \multirow{3}{*}{$\begin{array}{l}\text { Menstruation } \\
\text { history }\end{array}$} & Correlation coefficient $\mathrm{r}$ & 0.06818 & 0.1118 & 0.0000 \\
\hline & Significance level (p value) & $\mathrm{P}=0.3977$ & $\mathrm{P}=0.2887$ & $\mathrm{P}=1.0000$ \\
\hline & $95 \%$ Confidence interval for $r$ & -0.08993 to 0.2229 & -0.09520 to 0.3095 & -0.2458 to 0.2458 \\
\hline \multirow{3}{*}{$\begin{array}{l}\text { Blood group } \\
\text { (Rhesus } \\
\text { group) }\end{array}$} & Correlation coefficient $r$ & 0.01002 & 0.1488 & -0.2095 \\
\hline & Significance level (p value) & $\mathrm{P}=0.9008$ & $\mathrm{P}=0.1547$ & $\mathrm{P}=0.0966$ \\
\hline & $95 \%$ Confidence interval for $\mathrm{r}$ & -0.1468 to 0.1664 & -0.05667 to 0.3421 & -0.4330 to 0.03830 \\
\hline \multirow{3}{*}{$\begin{array}{l}\text { Duration of } \\
\text { infertility }\end{array}$} & Correlation coefficient $r$ & 0.06194 & 0.03087 & 0.1170 \\
\hline & Significance level ( $p$ value) & $\mathrm{P}=0.4409$ & $\mathrm{P}=0.7689$ & $\mathrm{P}=0.3571$ \\
\hline & $95 \%$ Confidence interval for $r$ & -0.09563 to 0.2165 & -0.1739 to 0.2331 & -0.1326 to 0.3527 \\
\hline
\end{tabular}

All the recruited primary and secondary infertility patients had normal range erythrocyte sedimentation rate (ESR), thyroid function test, and random blood sugar.

Out of 157 patients, abnormalities were detected in 125 patients during Hysterolaparoscopy and underwent various therapeutic interventions according to the detected abnormalities. In primary infertile patients, hysterolaparoscopy was positive in $77 / 93(82.8 \%)$ patients. In the secondary infertility, $48 / 64 \quad(\sim 75.0 \%)$ patients were detected with an abnormality on the Hysterolaparoscopy. Of the 125 patients with abnormal hysterolaparoscopic findings, 121 ( 96.8\%) patients experienced active therapeutic interventions in form of ovarian drilling, adhesiolysis, successful cannulation, fluid drainage, fulguration of white patches, septum resection and chocolate cystectomy. Out of 125, 4 patients with abnormal hysterolaparoscopic findings were not underwent active intervention. These patients have streak ovaries \& hypoplastic uterus, few small fibroids and adenomyosis in 1, 1 and 2 patients respectively.
After the 12 months follow-up, out of the 125 abnormal hysterolaparoscopic patients, 121 underwent active intervention and 43 patients $(35.5 \%)$ conceived during next 12 months. While out of 73 primary infertile patients $28(38.3 \%)$ were conceived after the active intervention during hysterolaparoscopy. Among the 48 secondary infertile patients, $15(\sim 31.2 \%)$ were conceived after the hysterolaparoscopic intervention. There was no statistical significant difference $(\mathrm{P} \sim 0.457)$ in the conception rate in primary and secondary infertile patients (Table 3). Among 32 patients with normal hysterolaparoscopic findings, 7 ( 21.8\%) patients were conceived within 12 months.

In present study we draw a correlation between the fertility outcome and age, BMI, duration of infertility, hemoglobin (gm), menstruation history \& Rhesus factor. All correlation with its $95 \% \mathrm{CI}$ is shown in the Table number 4 for combined and independent infertile patients. Authors found that high hemoglobin level is significantly correlated with the good fertility outcome in 
the female infertile patients, who underwent for endoscopic intervention.

\section{DISCUSSION}

Hysterolaparoscopy is used for both diagnostic and therapeutic purpose in female infertile patients. In the present study, authors assessed the impact of accessory parameters on outcome of hysterolaparoscopy in term of achieving pregnancy in the female infertile patients.

In present study, pelvic abnormalities were detected in $\sim 79.6 \%$ (125 patients) female infertile patients. Of 125 patients with abnormal hysterolaparoscopic findings, we performed active hysterolaparoscopic intervention in 121 patients $(\sim 96.8 \%)$. So, in this study, $\sim 96.8 \%$ of detected abdomino-pelvic pathologies were treated with hysterolaparoscopy without significant injuries to other parts of the reproductive system. We advised for regular sexual activity for all recruited infertile female patients and had taken the regular follow up of all recruited patients for 12 months at a interval of three months (With or without interventions). We found that out of 157 patients, 50 patients $(-31.7 \%)$ were conceived. In 121 patients with active hysterolaparoscopic intervention, 43 patients $(35.5 \%)$ were conceived.

In the accessory parameters, infertility outcome in the female infertile patients was not dependent on the age in present study. However the American College of Obstetricians and Gynecologists' Committee on Gynecologic Practice and the Practice Committee of the American Society for Reproductive Medicine stated that the fecundity of women decreases gradually but significantly beginning approximately at age 32 years and decreases more rapidly after age 37 years. ${ }^{15}$ In present study, all included patients are below the 35 year of age and average age for primary and secondary infertility was 26.6 and 29.3 years respectively. So this reason might be responsible for we did not observe the effect of the age on fertility outcome.

In other accessory parameter BMI, infertility outcome in the female infertile patients was not dependent on the BMI in present study. However most of the published literature shows that obesity decreases the fertility outcomes in infertile women however no one have mentioned the Cutoff for BMI to observed the decreased fertility. ${ }^{16,17}$ In present study average BMI for combined, primary and secondary infertile patients was $21.80 \mathrm{Kg} / \mathrm{m}^{2}$, $21.84 \mathrm{Kg} / \mathrm{m}^{2}$ and $21.7 \mathrm{Kg} / \mathrm{m}^{2}$ respectively. So most of the included patients are within the normal range of BMI and this reason might be responsible for we did not observe the effect of the BMI on fertility outcome.

In other accessory parameters like duration of infertility, menstruation history, Rhesus factor and hemoglobin levels, only hemoglobin levels was significantly associated with the fertility outcome. Spitzer D et al, found there was no correlation between the ovarian reserved and $\mathrm{ABO}$ and $\mathrm{Rh}$ blood group system. ${ }^{18} \mathrm{We}$ also observed there was no correlation between the Rh blood group system and fertility outcome. Wise LA et al, observed duration or intensity of menstrual flow were not appreciably associated with fecundability and similar observation we also appreciated in present study. ${ }^{19}$ In present study hemoglobin deficiency affect the female fertility in adverse way, because hemoglobin molecule carries the oxygen to the cells including ovary cells. So, in conditions of low hemoglobin level, low amount of oxygen will deliver to the cells, which adversely affects the maturation of the Ovulatory cells and affect the female fertility. ${ }^{20,21}$

The major limitation of present study is this was a single center study so inter-operator variability can lead to discrepancy in outcomes. This study was conducted in the limited geographical area so for better admiration of results, these studies should be conducted in large area.

\section{CONCLUSION}

Authors concluded hemoglobin level significantly affects the conception rate in female infertile patients, who underwent hysterolaparoscopic intervention. However, age, duration of infertility, Rhesus factor and body mass index does not affect the fertility outcome in these patients.

\section{REFERENCES}

1. Agrawal N, Yadav P, Fayyaz S, Kaur B. Is hysterolaparoscopy a real theranostic approach for anatomical barriers in female fertility? A future argument. Int J Reprod Contracept Obstet Gynecol. 2018;7:2423-8.

2. National Collaborating Centre for Women's and Children's Health. Fertility: assessment and treatment for people with fertility problems. London, United Kingdom: National Institute for Health and Clinical Excellence (NICE); 2013:1-63.

3. Practice Committee of American Society for Reproductive Medicine. Diagnostic evaluation of the infertile female: a committee opinion. Fertil Steril. 2012; 98(2):302-7.

4. Agrawal N, Sharma R. Correlation of Anti-Müllerian hormone with clinical, hormonal and ultrasonographic parameters in PCOS and normoovulatory women: an experience of single tertiary care center. Int J Gynaecol Obstet. 2018;30(4):23850868 .

5. Agrawal N, Fayyaz S. Can hysterolaparoscopic mediated chromopertubation obviate the need for hysterosalpingography for proximal tubal blockage?: An experience at a single tertiary care center. J Gynecol Obstet Hum Reprod. 2018.

6. Agrawal N, Fayyaz S. Evaluation of endoscopic procedures in terms of achieving pregnancy in female infertile patients: an experience at a single 
tertiary care center. J Gynecol Obstet Hum Reprod. 2018.

7. The Practice Committee of the American Society for Reproductive Medicine: Vaccination guidelines for female infertility patients. Fertil Steril. 2008;90(5):S169-71.

8. The ESHRE Capri Workshop Group: Diagnosis and management of the infertile couple: missing information. Hum Reprod Update. 2004;10(4):295307.

9. Jose-Miller AB, Boyden JW, Frey KA. Infertility. Am Fam Physician. 2007;75(6):849-56.

10. Macaluso M, Wright-Schnapp TJ, Chandra A, Johnson R, Satterwhite CL, PulverA, et al. A public health focus on infertility prevention, detection, and management. Fertil Steril. 2010;93(1):16.e1-10.

11. Vayena E, Peterson H, Adamson D, Nygren KG. Assisted reproductive technologies in developing countries: are we caring yet? Fertil Steril. 2009;92(2):413-6.

12. Vaid K, Mehra S, Verma M, Jain S, Sharma A, Bhaskaran S. Pan endoscopic approach "hysterolaparoscopy" as an initial procedure in selected infertile women. J Clin Diagn Res. 2014;8(2):95-8.

13. Agrawal N, Fayyaz S. Does type of intervention affects the endoscopic procedure outcome in female infertile patients? an experience at a single tertiary care centre. Int J Reprod Contracept Obstet Gynecol. 2019;8:192-9.

14. Hassa H, Aydin Y. The role of laparoscopy in the management of infertility. J Obstet Gynaecol. 2014;34(1):1-7.

15. American College of Obstetricians and Gynecologists Committee on Gynecologic Practice and Practice Committee. Female age-related fertility decline. Committee Opinion No. 589. Fertil Steril. 2014;101:633-4.

16. Pandey S, Pandey S, Maheshwari A, Bhattacharya S. The impact of female obesity on the outcome of fertility treatment. J Hum Reprod Sci. 2010;3(2):627.

17. Giviziez CR, Sanchez EG, Approbato MS, Maia MC, Fleury EA, Sasaki RS. Obesity and anovulatory infertility: A review. JBRA Assist Reprod. 2016;20(4):240-5.

18. Spitzer D, Corn C, Stadler J. Implications of Blood Type for Ovarian Reserve and Infertility - Impact on Oocyte Yield in IVF Patients. Geburtshilfe Frauenheilkd. 2014;74(10):928-32.

19. Wise LA, Mikkelsen EM, Rothman KJ. A prospective cohort study of menstrual characteristics and time to pregnancy. Am $\mathrm{J}$ Epidemiol. 2011;174(6):701-9.

20. Iron status and reproduction in US women: National Health and Nutrition Examination Survey, 19992006. PLoS One. 2014;9(11):e112216.

21. Chavarro JE, Rich-Edwards JW, Rosner BA, Willett WC. Iron intake and risk of ovulatory infertility. Obstet Gynecol. 2006;108:1145-52.

Cite this article as: Agrawal N, Yadav P, Fayyaz S, Jain TK. Do accessory parameters affect the outcome of the endoscopic procedures in female infertile patients?: an experience at a single tertiary care center Int J Reprod Contracept Obstet Gynecol 2019;8:2054-9. 